\title{
Improvement effect of nitrogen fertilizer and plant density on wheat (Triticum aestivum L.) seed deterioration and yield
}

\author{
Hedieh Mosanaei ${ }^{1}$, Hossein Ajamnorozi ${ }^{1 *}$, Mohammad Reza Dadashi ${ }^{1}$, Abolfazleh Faraji ${ }^{2}$, \\ Mohammad Pessarakli ${ }^{3}$ \\ ${ }^{1}$ Agronomy Department, Agriculture Faculty, Islamic Azad University of Gorgan, Iran, ${ }^{2}$ Associated Professor, Horticulture and Agronomy \\ Department, Golestan Agricultural and Natural Resources Research and Education Center, Agricultural Research, Education and Extension \\ Organization (AREEO), Gorgan, Iran, ${ }^{3}$ Professor, School of Plant Science, University of Arizona, Tucson, AZ, 85721, USA
}

\section{A B S T R A C T}

\begin{abstract}
In order to study the effect of seed deterioration, plant density and nitrogen fertilizer application on yield, yield components and some qualitative traits of wheat, a field experiment was conducted in Golestan province of Iran, as split factorial in the randomized complete block design, with four replications in two growing seasons, 2014-2015 and 2015-2016. The experimental treatments included seed quality at 4 levels (control, 15, 30, and 45 hours of accelerated deterioration), plant density at two levels $\left(350\right.$ and 420 plants $\left./ \mathrm{m}^{2}\right)$ and nitrogen consumption at 3 levels (recommended rate, 15 and 30 percentages higher than the recommended rate, i.e., 125, 143.75, and $162.5 \mathrm{~kg} \mathrm{~N}$ fertilizer ha ${ }^{-1}$, respectively). All quantitative traits (plant height, spike length, number of seeds per spike, number of spikelets per spike, weight of 1000 seed, grain yield, straw yield, biological yield and harvest index) and quality traits (yield and protein content, nitrogen content, yield and starch content) were significantly different in different years. Application of recommended rate of nitrogen fertilizer in the first and the second year resulted in the highest average of number of seeds per spike and spike length. The highest grain yield was achieved in the recommended and 30\% higher than the recommended application rate of nitrogen fertilizer $(4061.9$ and $4166.3 \mathrm{~kg} / \mathrm{ha}$, respectively) in the second year. Seed deterioration caused a significant reduction in yield and the yield components, so the highest level of seed deteriorations in the first and the second years decreased 34.11 and $22.63 \%$ of the grain yield compared to the control treatment. The highest protein content was achieved in the second year with the application of nitrogen $30 \%$ higher than the recommended rate (with a mean of $623.6 \mathrm{~kg} / \mathrm{ha}$ ), which increased by about $23 \%$ compared to the overall average. Seed deterioration reduced the starch content, so that the highest mean was in non-deterioration in the second year $(68.13 \%)$, which increased by $10 \%$ compared with that of the overall average. The lowest starch content was achieved at the highest level of deterioration (45 hours) in the first year $(55.63 \%)$. In general, the results indicated that seed deterioration had negative effects on quantitative and some qualitative traits, but the application of more nitrogen fertilizer and higher plant density reduced the negative effects of deterioration and improved grain yield and quality.
\end{abstract}

Keywords: Seed deterioration; Urea; Protein; Harvest index; Yield; Starch

\section{INTRODUCTION}

The cereals produce a major part of world food and feed. In general, about $70 \%$ of the world's food comes from cereals. In this regard, wheat (Triticum aestivum L.) is considered as one of the important food sources among the major crops in the world. It seems that the onset of human agriculture began with wheat planting (Sramkova et al., 2009; Brenchley et al., 2012). These plants grow in a wide range of weather conditions across the world. One of the most important factors in the production of wheat is the quality of the seeds that have been planted. The quality of wheat seeds is affected by many factors, including cultivar, genetic purity, physical purity, vitality, germination percentage, and seed viability ( $\mathrm{Lv}$ et al., 2016).

Seed deterioration is a physiological phenomenon that occurs after ripening of the seeds and in the post-harvest period, in the conditions of high temperature, humidity and lack of oxygen, the seed storage environment gradually begins to degrade the seed structure, increase respiration and activity of the enzymes in seed and permeability of the

\footnotetext{
${ }^{*}$ Corresponding author:

Hossein Ajamnorozi, Agronomy Department, Agriculture Faculty, Islamic Azad University of Gorgan, Iran. E-mail: ajamnorozei@yahoo.com
}

Received: 06 August 2017; 
cell membrane, that results in reduced viability, seedling, and seedling vigor and ultimately product yield (Garcia del Moral et al., 2003). Seed deterioration tests have the ability to distinguish between strong and weak (viable and non-viable) seeds (Tekrony and Egli, 1991). Reducing seed yield is a result of seed deterioration due to seed aging, pre- and post-harvest problems, and one of the important goals of seed breeding is the production of healthy and strong seeds against environmental conditions (Powell, 1998). The maximum seed yields in wheat and corn, that are harvested after seed drying, are obtained before the physiological ripening, but the seed strength of the storage period obviously is affected. Seeds deterioration during storage leads to a decrease in seed quality (Basra et al., 2003). Due to the deterioration of seed, seed vigor is the first component of seed quality that decreases, followed by a decrease in germination percent and viability. Therefore, having a high-quality seed, during the storage conditions is necessary to maintain vitality, which results in high yields (Mohsen Nasab et al., 2010).

Sufficient nitrogen for an early crop is very important for the onset of leaves and floral primordia (Warraich et al., 2002). Potential wheat yield is mainly influenced by nitrogen fertilization during the vegetative growth. Increasing the amount of nitrogen during the vegetative growth period increases the yield and the grain protein content. An acceptable nitrogen level is required to maximize protein yield (Brown et al., 2005). It was reported that with increasing nitrogen, plant height, the number of spikes per plant, the number of seeds per spike, grain weight per spike, leaf area and wheat grain yield were significantly higher than that of the control (Sabbr et al., 2011). Nitrogen increases the production of biomass and increases the possibility of retransmission of photosynthetic materials, producing more seeds per spike and better filling them after flowering, which will increase grain yield (Shanggan et al., 2000). It seems nitrogen increases growth by affecting cell division as well as contributing to the absorption of other elements by the plant; hence increasing nitrogen can improve plant growth indices (Asadie et al., 2013). Numerous researchers have reported the positive effect of nitrogen application on the nitrogen concentration in grains (Albrizio et al., 2010; Ercoli et al., 2008; Qi et al., 2006). Also, the effect of nitrogen application has been reported to increase protein content in cereals (Dianne et al., 2006).

The yield of each crop is the result of inter-plant and intraplant competition in the growth environments. Maximum yield is achieved when the competition reaches its minimum and the plant can maximize the usage of the environmental factors. Suitable density and balanced distribution of plants per unit area result in better use of moisture, nutrients, light and increased yield. In general, determination of the best plant density is one of the most important requirements in agronomic planning for achieving high yield with optimal quality (Kheshtzar and Siadat, 2015).

Hiltbrunner et al., (2007) reported that the optimum planting densities in wheat are the key to achieving maximum yield. It is believed that for each cropping system and each cultivar, a specific and desirable density is required. Additionally, in the recommendations for density, consideration should be given to the specific climate conditions of each area and to avoid general recommendations (Xi-haun et al., 2008). Royo et al. (2006) stated that grain yield depends on the number of plants per unit area, spikes per plant, spikelets per spike, grain per spike and single grains, these important components of determining the yield are influenced strongly by resource availability, including seed quality and nitrogen.

Plant nutrition (especially, with the key nitrogen element) and cultivated seed density can be applied to compensate for the adverse effects of wheat seed deterioration. Due to the importance of wheat in human nutrition and the effect of seed deterioration on yield reduction, the aim of this study was to investigate the changes in yield and yield components and also some qualitative traits (protein content, nitrogen and starch contents of the grain) of wheat under the influence of higher levels of nitrogen fertilizer and planting density and different seed qualities.

\section{MATERIAL AND METHODS}

This study was conducted as a split factorial experiment in a randomized complete block design with 4 replications in the village of Balajadeh, located 25 kilometers west of Gorgan, Golestan province, Iran, during two years, 2014-2015 and 2015-2016. The area is N 36 50' 19" and E $054^{\circ} 26^{\prime} 05^{\prime \prime} 165 \mathrm{~m}$ above sea level. Other climate information is given in Table 1.

Experimental factors included seed quality at 4 levels, including control, 15, 30, and 45 hours of deteriorating, planting density at two levels, including 350 and 420 plants per square meter and nitrogen consumption at 3 levels, including the recommended rate, 15 , and $30 \%$ higher than the recommended rate $(125$, $143.7,162.5 \mathrm{~kg}$ nitrogen per hectare, respectively).

Seed deterioration treatments were carried out at a temperature of $42^{\circ} \mathrm{C}$ and relative humidity of $95 \%$. For this purpose, wheat seeds of the Morvarid cultivar (prepared by the Seed and Plant Institute of Karaj) were placed in a lace hanging in containers containing water and placed in an oven for 15, 30, and 45 hours. Seeds were placed in accelerated condition at about $95 \%$ relative humidity (Peng et al., 2011). 
Table 1: The average of maximum temperature, minimum temperature, radiation and total rainfall during the growth period of the wheat plant during two years and in comparison with long-term statistics (40 years) under the weather conditions of the experimental site

\begin{tabular}{|c|c|c|c|c|c|c|c|c|c|c|c|c|}
\hline \multirow[t]{2}{*}{ Months } & \multicolumn{3}{|c|}{ Maximum temperature $\left({ }^{\circ} \mathrm{C}\right)$} & \multicolumn{3}{|c|}{ Minimum temperature $\left({ }^{\circ} \mathrm{C}\right)$} & \multicolumn{3}{|c|}{ Rainfall (mm) } & \multicolumn{3}{|c|}{ Radiation (mega joule/m²) } \\
\hline & 2014-15 & 2015-16 & long time & 2014-15 & $2015-16$ & long time & 2014-15 & 2015-16 & long time & 2014-15 & 2015-16 & long time \\
\hline December & 14.9 & 15.1 & 16 & 5.8 & 6.2 & 6.3 & 71.9 & 66.8 & 52.3 & 7.1 & 6.5 & 23.2 \\
\hline January & 8 & 9.2 & 12.9 & -2.3 & 3.4 & 3.8 & 16.5 & 20.5 & 56.9 & 9.3 & 10.3 & 9.4 \\
\hline February & 10.7 & 10.2 & 12.4 & 0.4 & 1.2 & 3.4 & 55.8 & 41.5 & 57.6 & 10.4 & 9.8 & 11.2 \\
\hline March & 18.5 & 19.8 & 14.5 & 6.1 & 5.8 & 5.2 & 38.1 & 45.6 & 73.3 & 14.3 & 16.2 & 14.1 \\
\hline April & 23.5 & 22.5 & 19.3 & 11.3 & 12.4 & 9 & 28.8 & 42.5 & 60.3 & 13.9 & 15.8 & 17.4 \\
\hline May & 16.6 & 18.5 & 24.9 & 13.9 & 14.5 & 13.8 & 24.8 & 38.9 & 47.2 & 19.2 & 21.2 & 20.1 \\
\hline June & 29.9 & 28.5 & 29.6 & 18.5 & 19.5 & 18.4 & 14.5 & 20.5 & 35.7 & 21 & 24.6 & 21.6 \\
\hline July & 35.8 & 34.2 & 32 & 20.6 & 19.8 & 21.9 & 12.3 & 19.5 & 23.1 & 20.3 & 24.2 & 21.2 \\
\hline
\end{tabular}

Before planting, soil samples were taken at the depth of 0 to $30 \mathrm{~cm}$ and analyzed in the soil analysis laboratory for their physical and chemical properties (Table 2). The test site was prepared with supplementary land preparation including the use of disk and cultivator, then ready to be planted. Before planting, based on soil analysis results, phosphorus fertilizer was applied from a source of superphosphate $\left(\mathrm{P}_{2} \mathrm{O}_{5}\right)$ at a rate of $90 \mathrm{~kg} / \mathrm{h}$. Seeds were disinfected with the anti-fungal agent Mancozeb before planting in a ratio of two per thousand and then cultivated at a depth of 3-5 cm. For each experimental plot, 5 lines 5 meters long with $25 \mathrm{~cm}$ spacing, and seed rate based on the type of density were planted. In the final stages of growth, sampling was performed using existing plants in $0.6 \mathrm{~m}^{2}$ of each plot to measure the traits. Plant height, spike length, biological yield, harvest index (economic yield/biological yield $\times 100$ ) (Rahimizadeh et al., 2010), the number of spikes per unit area and the number of seeds per spike were measured.

After harvest, grain dry weight was evaluated and prepared for qualitative traits. The phenolic acid sulfuric acid protocol was used to determine the starch content (Hellubust and Caraigia, 1978). Nitrogen measurements were performed by Kjeldahl using Digestor 2040 cooker from Foss sector and Kejeltec Analysis Unit 2300 allautomatic machine. The following equation was used to determine the protein content of the seeds. The protein conversion factor for wheat is 5.83 (Parvane, 2005). For protein yield and starch yield, the percentage of protein and starch content were multiplied in grain yield, respectively.

Protein percentage of grain $=$ Protein conversion factor $x$ Nitrogen percent

\section{Statistical analysis}

Before the component analysis, Bartlett's test was used to ensure the uniformity of the test error variance. The component analysis was performed by assuming the randomness of the year and the constant of experimental treatments for the desired traits. Due to the uniformity of the variance of the trait error, a composite analysis was performed for all of them. Data analysis and component analysis of time were performed using SAS 9.2 software and the means of the data were compared using LSD test at $5 \%$ probability level.

\section{RESULTS}

\section{Plant height}

The results of the analysis of variance showed that the effect of year, nitrogen applications, seed deterioration and the interaction effect of density and deterioration at $1 \%$ probability level and interactions of nitrogen and deterioration and density at 5\% probability level were significant (Table 3). The highest plant height was found in the second year and at the 15 and 30\% higher than the recommended application rates of nitrogen (89.26 and $90.03 \mathrm{~cm}$, respectively) and the lowest mean was achieved in the first year at the recommended application rate of nitrogen $(84.03 \mathrm{~cm})$ (Table 4). Among the levels of seed deterioration, the highest plant height was observed in the non-deteriorating in the first and the second years (91.61 and $93.63 \mathrm{~cm}$ ), and the lowest mean was at 45 hours of deteriorating in the first year $(81.29 \mathrm{~cm})$ (Tables 5 and 6 ).

The nitrogen fertilizer showed a significant effect on wheat plant height in the present study that is in agreement with the results reported be Moghadam et al. (1997). Increasing nitrogen application increases the protein content of the cells, as a result cell size increases; consequently, the leaf area is enlarged, followed by photosynthetic activity and ultimately leads to an increase in plant height (Wysocki et al., 2007). Nitrogen can increase wheat growth by affecting cell division as well as assisting in the absorption of nutrient elements by the plant; hence the increase in nitrogen can increase the shoot height of the wheat plant (Asadie et al., 2013). 
Mosanaei, et al.: Effect of nitrogen and plant density on wheat

Table 2: Physical and chemical properties of the soil in the field of the experimental site during the two years growth

\begin{tabular}{lccccccccccc}
\hline Soil texture & Sand $\%$ & silt $\%$ & Clay $\%$ & $\mathbf{K}(\mathbf{p p m})$ & $\mathbf{P}(\mathbf{p p m})$ & Total N & O. C 1\% & TNV & pH & EC (dS/m) & Depth of soil $(\mathbf{c m})$ \\
\hline Clay loam & 28 & 35 & 36 & 306 & 10.6 & 0.12 & 2.1 & 26.4 & 8.2 & 2.87 & $0-30$
\end{tabular}

Table 3: Combined ANOVA of yield and yield components of wheat in two years (2015-2016)

\begin{tabular}{|c|c|c|c|c|c|c|c|c|c|c|}
\hline \multirow[t]{2}{*}{ Source of variation } & \multicolumn{10}{|c|}{ Mean Square (MS) } \\
\hline & df & $\begin{array}{l}\text { Plant } \\
\text { height }\end{array}$ & $\begin{array}{l}\text { Spike } \\
\text { length }\end{array}$ & $\begin{array}{l}\text { Number } \\
\text { of seeds } \\
\text { per spike }\end{array}$ & $\begin{array}{l}\text { Number } \\
\text { of spikelet } \\
\text { per spike }\end{array}$ & $\begin{array}{c}\text { Weight } \\
\text { of } 1000 \\
\text { seed }\end{array}$ & Seed yield & Straw yield & $\begin{array}{l}\text { Biological } \\
\text { yield }\end{array}$ & $\begin{array}{c}\text { Harvest } \\
\text { index }\end{array}$ \\
\hline Year (y) & 1 & $548.5^{\star \star}$ & $3.31^{* *}$ & $454.0^{\star *}$ & $4.19^{*}$ & $56.98^{* *}$ & $36175116^{\star \star}$ & $121980850^{* *}$ & $291011850^{\star \star}$ & $840.0^{\star *}$ \\
\hline$r(y)$ & 6 & $73.5^{\star *}$ & $0.65 \mathrm{~ns}$ & $51.37 \mathrm{~ns}$ & $2.01 \mathrm{~ns}$ & $2.06 \mathrm{~ns}$ & $1426250^{* *}$ & 526399 ns & 2920819 ** & $38.51 \mathrm{~ns}$ \\
\hline Nitrogen $(\mathrm{N})$ & 2 & $104.8^{* *}$ & $8.75^{\star *}$ & $658.5^{\star *}$ & $16.50^{* *}$ & $1.05 \mathrm{~ns}$ & $155063^{*}$ & 610622 ns & $3091209 \mathrm{~ns}$ & $60.73 \mathrm{~ns}$ \\
\hline Plant density (D) & 1 & $0.81 \mathrm{~ns}$ & $0.32 \mathrm{~ns}$ & $263.6^{\star \star}$ & 1.83 ns & $0.93 \mathrm{~ns}$ & 1130558 ns & 1509993 * & 5253699 * & $0.20 \mathrm{~ns}$ \\
\hline$N \times D$ & 2 & $28.38 \mathrm{~ns}$ & $2.61^{* *}$ & $177.8^{\star *}$ & $1.64 \mathrm{~ns}$ & $24.87^{\star *}$ & 123107 ns & $1571096^{*}$ & 2792407 ns & $50.25 \mathrm{~ns}$ \\
\hline $\mathrm{y} \times \mathrm{N}$ & 2 & $1.95 \mathrm{~ns}$ & $0.02 \mathrm{~ns}$ & $1.47 \mathrm{~ns}$ & $0.54 \mathrm{~ns}$ & $0.50 \mathrm{~ns}$ & 167222 ns & $1058260 \mathrm{~ns}$ & $1208691 \mathrm{~ns}$ & $80.71^{*}$ \\
\hline$y \times D$ & 1 & $0.07 \mathrm{~ns}$ & $0.02 \mathrm{~ns}$ & $0.30 \mathrm{~ns}$ & $0.49 \mathrm{~ns}$ & $0.06 \mathrm{~ns}$ & $1266.9 \mathrm{~ns}$ & 195776 ns & $165545 \mathrm{~ns}$ & $15.06 \mathrm{~ns}$ \\
\hline $\mathrm{y} \times \mathrm{N} \times \mathrm{D}$ & 2 & $0.54 \mathrm{~ns}$ & $0.02 \mathrm{~ns}$ & $0.24 \mathrm{~ns}$ & $0.58 \mathrm{~ns}$ & $0.14 \mathrm{~ns}$ & $769065 \mathrm{~ns}$ & 886269 ns & 2977506 ns & 26.14 ns \\
\hline Error & 12 & 62.19 & 0.72 & 82.13 & 5.11 & 4.09 & 535576 & 804073 & 2111335 & 33.80 \\
\hline Seed quality $(\mathrm{Q})$ & 3 & $725.9^{\star \star}$ & $9.56^{\star *}$ & $806.8^{\star \star}$ & $30.79^{\star \star}$ & $25.63^{* *}$ & $6412528^{\star *}$ & $7028629^{* *}$ & $15608042^{* *}$ & $410.03^{\star *}$ \\
\hline$N \times \mathrm{Q}$ & 6 & $22.27 \mathrm{~ns}$ & $0.43 \mathrm{~ns}$ & $19.41 \mathrm{~ns}$ & $2.14 \mathrm{~ns}$ & $4.84 \mathrm{~ns}$ & 299993 ns & 56064 ns & $248050 \mathrm{~ns}$ & $23.49 \mathrm{~ns}$ \\
\hline $\mathrm{D} \times \mathrm{Q}$ & 3 & $139.57^{\star *}$ & $1.15^{*}$ & $19.04 \mathrm{~ns}$ & $4.19^{*}$ & $4.35 \mathrm{~ns}$ & 401294 ns & 150397 & $1076190 \mathrm{~ns}$ & $31.36 \mathrm{~ns}$ \\
\hline $\mathrm{N} \times \mathrm{D} \times \mathrm{Q}$ & 6 & $55.64^{*}$ & $0.25 \mathrm{~ns}$ & $46.01 \mathrm{~ns}$ & $0.83 \mathrm{~ns}$ & $3.98 \mathrm{~ns}$ & 701323 ns & 257323 ns & 1168811 ns & $33.54 \mathrm{~ns}$ \\
\hline$y \times Q$ & 3 & $1.53 \mathrm{~ns}$ & $0.004 \mathrm{~ns}$ & $5.11 \mathrm{~ns}$ & $0.48 \mathrm{~ns}$ & $71.48^{\star \star}$ & 277594 ns & $1941609^{* *}$ & $1612381 \mathrm{~ns}$ & $141.7^{\star \star}$ \\
\hline $\mathrm{y} \times \mathrm{N} \times \mathrm{D} \times \mathrm{Q}$ & 15 & $0.53 \mathrm{~ns}$ & $0.01 \mathrm{~ns}$ & $1.28 \mathrm{~ns}$ & $0.52 \mathrm{~ns}$ & $4.68 \mathrm{~ns}$ & $458410 \mathrm{~ns}$ & 289342 ns & 854587 ns & $26.10 \mathrm{~ns}$ \\
\hline Experimental Error & 126 & 22.03 & 0.43 & 26.48 & 1.23 & 4.44 & 358896 & 409330 & 1082688 & 22.49 \\
\hline CV (\%) & - & 5.37 & 9.38 & 13.66 & 7.44 & 5.87 & 16.51 & 19.39 & 15.02 & 9.99 \\
\hline
\end{tabular}

${ }^{*}$ and ${ }^{* *}$ : Significant at $5 \%$ and $1 \%$ probability levels, respectively. ns: nonsignificant

Table 4: Mean comparison of Nitrogen levels on yield and yield components of wheat in two years (2015-2016)

\begin{tabular}{|c|c|c|c|c|c|c|c|c|c|c|}
\hline \multirow[t]{2}{*}{ Nitrogen fertilizer levels } & \multicolumn{2}{|c|}{$\begin{array}{l}\text { Plant height } \\
\text { (cm) }\end{array}$} & \multicolumn{2}{|c|}{$\begin{array}{l}\text { Spike length } \\
(\mathrm{cm})\end{array}$} & \multicolumn{2}{|c|}{$\begin{array}{l}\text { Number of seeds } \\
\text { per spike }\end{array}$} & \multicolumn{2}{|c|}{$\begin{array}{c}\text { Number of spikelet } \\
\text { per spike }\end{array}$} & \multicolumn{2}{|c|}{$\begin{array}{l}\text { Weight of } 1000 \\
\text { seed (gr) }\end{array}$} \\
\hline & $1^{\text {st }}$ year & $2^{\text {nd }}$ year & $1^{\text {st }}$ year & $2^{\text {nd }}$ year & $1^{\text {st }}$ year & $2^{\text {nd }}$ year & $1^{\text {st }}$ year & $2^{\text {nd }}$ year & $1^{\text {st }}$ year & $2^{\text {nd }}$ year \\
\hline $\begin{array}{l}\text { Recommended amount of } \\
\text { nitrogen }\end{array}$ & $84.03 \mathrm{c}$ & $\begin{array}{c}87.80 \\
a b\end{array}$ & $7.30 \mathrm{a}$ & $7.60 \mathrm{a}$ & $39.91 \mathrm{a}$ & $42.68 \mathrm{a}$ & $15.31 \mathrm{a}$ & $15.49 \mathrm{a}$ & $35.30 \mathrm{a}$ & $36.33 \mathrm{a}$ \\
\hline $\begin{array}{l}15 \text { percent higher than } \\
\text { advised amount of nitrogen }\end{array}$ & $86.17 \mathrm{~b}$ & $89.26 \mathrm{a}$ & $6.60 c$ & $6.87 \mathrm{~b}$ & $33.52 \mathrm{c}$ & $36.89 \mathrm{~b}$ & $14.84 b$ & $15.05 a b$ & $35.19 \mathrm{a}$ & $36.48 \mathrm{a}$ \\
\hline $\begin{array}{l}30 \text { percent higher than } \\
\text { advised amount of nitrogen }\end{array}$ & $86.74 b$ & $90.03 \mathrm{a}$ & $6.81 \mathrm{~b}$ & $7.04 a b$ & $\begin{array}{l}34.96 \\
b c\end{array}$ & $\begin{array}{c}38.06 \\
a b\end{array}$ & \multicolumn{2}{|l|}{$14.13 \mathrm{c}$} & $35.57 \mathrm{a}$ & $36.52 \mathrm{a}$ \\
\hline Mean & \multicolumn{2}{|c|}{87.33} & \multicolumn{2}{|c|}{7.03} & \multicolumn{2}{|c|}{37.67} & \multicolumn{2}{|c|}{14.91} & \multicolumn{2}{|c|}{35.89} \\
\hline \multirow[t]{2}{*}{ Nitrogen fertilizer levels } & \multicolumn{3}{|c|}{ Seed yield (Kg/ha) } & \multicolumn{2}{|c|}{ Straw yield (Kg/ha) } & \multicolumn{3}{|c|}{ Biological yield (Kg/ha) } & \multicolumn{2}{|c|}{ Harvest index (\%) } \\
\hline & $1^{\text {st }}$ year & \multicolumn{2}{|c|}{$2^{\text {nd }}$ year } & $1^{\text {st }}$ year & $2^{\text {nd }}$ year & $1^{\text {st }}$ year & & jear & $1^{\text {st }}$ year & $2^{\text {nd }}$ year \\
\hline Advised amount of nitrogen & $3227.9 \mathrm{~b}$ & 4061 & & $6.3 \mathrm{~b}$ & $4146.3 \mathrm{a}$ & $5494.2 \mathrm{~b}$ & & $3.2 \mathrm{a}$ & $47.61 \mathrm{a}$ & $49.20 \mathrm{a}$ \\
\hline $\begin{array}{l}15 \text { percent higher than } \\
\text { advised amount of nitrogen }\end{array}$ & $2971.3 \mathrm{c}$ & 3954 & & $0.5 \mathrm{~b}$ & $4051.3 \mathrm{a}$ & $5501.8 \mathrm{~b}$ & & $5.6 \mathrm{a}$ & $37.11 \mathrm{a}$ & 49.39 a \\
\hline $\begin{array}{l}30 \text { percent higher than } \\
\text { advised amount of nitrogen }\end{array}$ & $3378.9 \mathrm{~b}$ & 4166 & & $0.3 \mathrm{~b}$ & $4091.9 \mathrm{a}$ & $6089.1 \mathrm{~b}$ & & $3.1 \mathrm{a}$ & $44.86 \mathrm{a}$ & $50.27 \mathrm{a}$ \\
\hline Mean & & 626.7 & & 3299 & & & 6926.1 & & 47. & \\
\hline
\end{tabular}

In each column, means with similar letters have no significant difference at the $5 \%$ probability level, based on the LSD test

\section{Spike lengths}

The results of the analysis of variance showed that the effect of year, nitrogen, seed deterioration and interaction of nitrogen in density and density in deteriorating were significant at $1 \%$ probability level on spike length (Table 3 ). According to the results of the mean comparison, the highest spike length was observed in the first and the second years in the application of nitrogen fertilizers at the recommended rates $(7.30$ and $7.60 \mathrm{~cm}$, respectively) and the lowest mean was achieved in nitrogen rate $15 \%$ higher than the recommended rate in the first year $(60.6 \mathrm{~cm})$ (Table 4).

Among the seed deterioration levels, the highest spike length was observed in the non-deterioration treatment in both years $(7.43$ and $7.67 \mathrm{~cm})$ and in deterioration of 15 hours in the second year $(7.36 \mathrm{~cm})$. The lowest spike length was obtained at the highest level of deterioration (45 hours) with a mean of $6.39 \mathrm{~cm}$ (Table 6). Sirjastava and 
Mosanaei, et al.: Effect of nitrogen and plant density on wheat

Table 5: Grouping the mean effect of plant density on yield and yield components of wheat in two years (2015-2016)

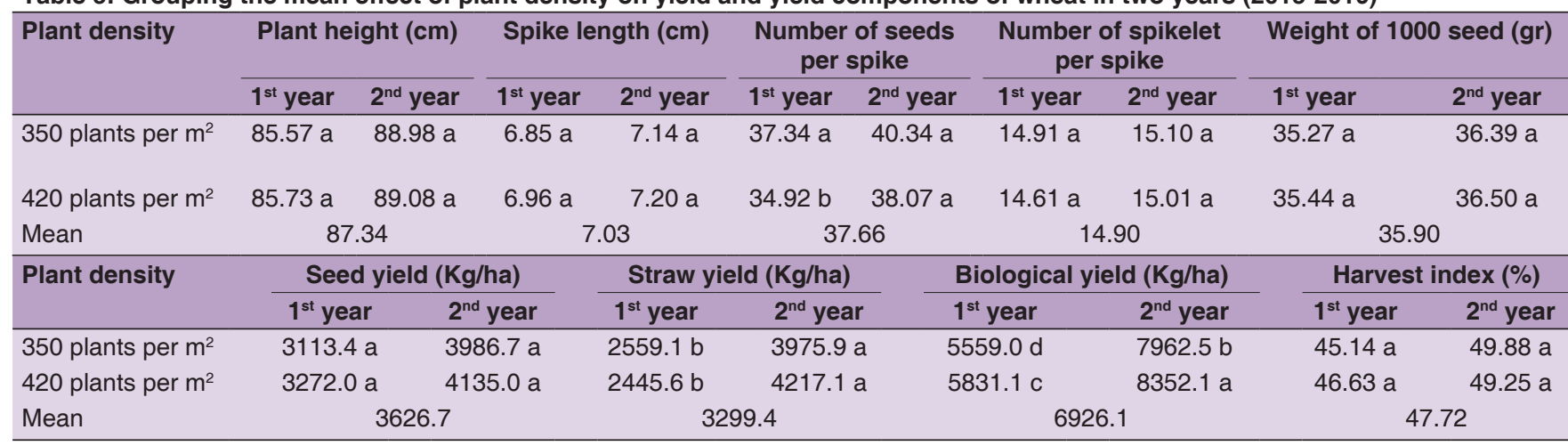

In each column, means with similar letters have no significant difference at the $5 \%$ probability level, based on the LSD test

Table 6: Grouping the mean effect of seed quality on yield and yield components of wheat in two years (2015-2016)

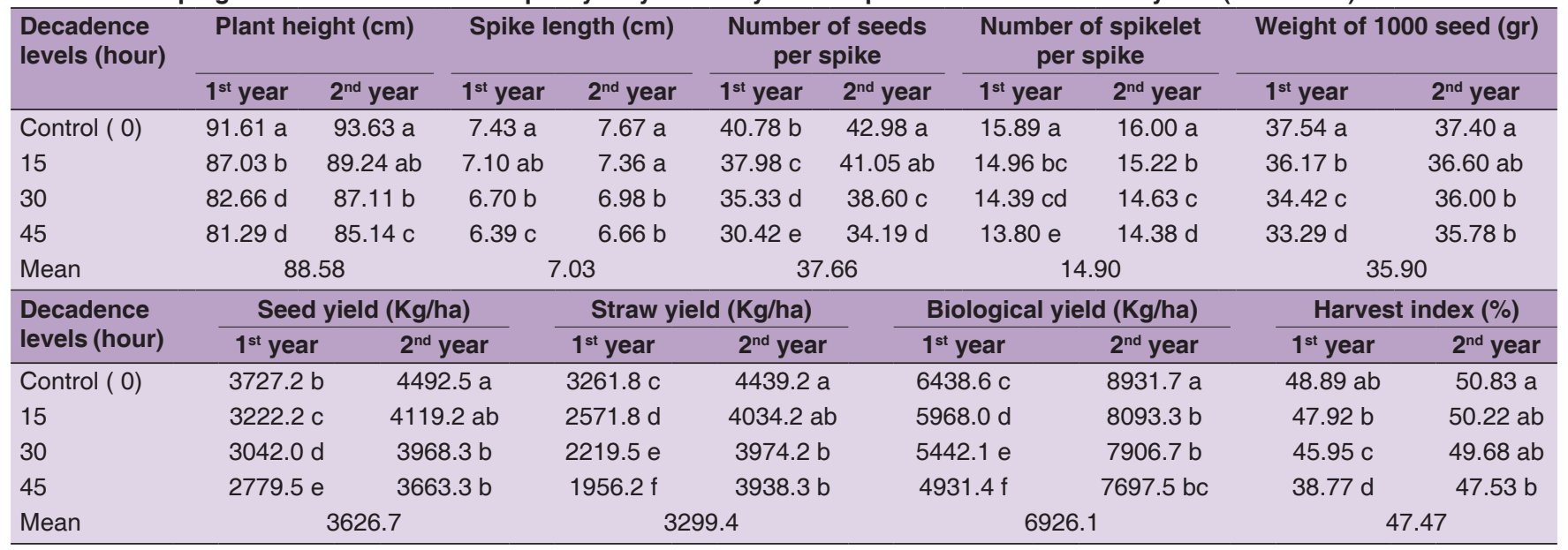

In each column, means with similar letters have no significant difference at the $5 \%$ probability level, based on the LSD test

Mehrotra (1981) also observed that during the two years of the experiment the use of nitrogen fertilizer increased the spike length. The results of these investigators (Sirjastava and Mehrotra, 1981) are in agreement with the results of the present study.

\section{Number of seeds per spike}

Analysis of variance showed the significant effect of year, nitrogen, density, deterioration and interaction of nitrogen fertilizer in deterioration was significant on grain number per spike (Table 3). The highest number of seeds per spike was achieved in the application of nitrogen fertilizer based on the recommended rate in the first and the second years (39.91 and 42.68, respectively) and the lowest mean was in the nitrogen application rate of $15 \%$ higher than the recommended rate (33.52) (Table 4). Among plant densities, except for the density of 420 plants $/ \mathrm{m}^{2}$ in the first year that was the lowest mean of this trait; other treatments had the highest average number of seeds per spike (Table 5). Among the levels of deterioration, the highest number of grain per spike was found at the level of non-deterioration in the second year (42.98) and the lowest mean was found at the highest level of deterioration (45 hours) (30.42)
(Table 6). According to the research of Akbari Moghaddam (2011), the effect of nitrogen fertilizer on the number of wheat spikes was significant, which was consistent with the results of the present study. Application of appropriate nitrogen fertilizer rate can reduce the number of the seeds deterioration per spike that may reduce the grain yield (Seiling et al., 2005). Nitrogen increases the biomass production and increases the possibility of retransmission of photosynthetic materials, producing more seeds per spike and better filling them after flowering, which will increase grain yield (Shanggan et al., 2000). Hastrop et al., (1993) also showed that the number of grain per spike in deterioration conditions was significantly reduced compared to the normal condition.

\section{Number of spikelets per spike}

The results of the analysis of variance showed that the effect of year, nitrogen, and deterioration and the effect of interaction density in deterioration were significant on spikelet number per spike (Table 3). The highest number of spikelets per spike was achieved in the nitrogen applied to the recommended rate at the first and the second years (15.31 and 15.49 numbers), and the lowest mean of 
this trait was obtained at 30\% higher nitrogen rate than the recommended rate in the first year (14.13 number) (Table 4). According to the results of the mean comparison, the highest number of spikelets per spike was obtained in the non-deterioration of seed at the first and the second years (15.89 and 16.00). The lowest mean was also at the 45 hours of deteriorating (13.80) (Table 6). The correct and proportional nitrogen application rate of fertilizers increases wheat grain yield by increasing the number of spikes per unit area, and increasing the number of seeds per spike has a lower role in raising the yield (Fowler and Brydon, 2001). Researchers reported that the increase in nitrogen consumption increases the number of spikes per unit area, which can increase vegetative growth and, consequently, increase the amount of tillering due to nitrogen consumption. In such a situation, the number of fertilized tillers per unit area increases and the number of spikes per unit area also increases (Donald, 1986; Nourmohammadi et al., 2010).

\section{Weight of 1000 seed}

Based on the results of the analysis of variance, the effect of year, deterioration and interaction effect of nitrogen in density was significant (Table 3). The results of the mean comparison showed that the highest weight of 1000 seed was obtained in zero hours of deteriorating level at the first and the second years (37.54 and $37.40 \mathrm{~g}$ ), and the lowest mean of this trait was achieved in 45 hours of seed deteriorating at the first year $(33.29 \mathrm{~g}$ ) (Table 6). The weight of 1000 seeds is one of the important qualitative criteria of seed, which is a function of seed rate and grain filling period. The higher the weight of 1000 seeds caused the higher the percentage of plant emergence and the increase in yields (Gorbani et al., 2005). Any factor that adversely affects the weight of 1000 seeds has a decreasing effect on yield. Morillo et al. (2012) in their research, reported that the increase in grain yield was due to an increase in the number of spikes per unit area, while in some cultivars more than half of the increase in grain yield was due to the increase in the number of seeds per spike with increasing grain weight or both traits. The reduction in the weight of 1000 seeds in high densities may be due to the superiority of vegetative organs in competing with reproductive organs (Modarresi et al., 2002). In a test conducted on the barley plant, effect of seed deterioration was significant on the weight of 1000 seeds and the weight of the seeds was reduced (Soltani et al., 2009). McDonald et al. (2004) investigated the effect of deterioration corn and sorghum seeds, showed that the higher the weight of 1000 seed caused the higher the amount of food supply and consequently increasing the seed quality and the final yield. The high weight of 1000 seeds is one of the reasons for the high yield and the low weight of 1000 seeds can be due to low seed quality because it is one of the yield factors. This variable depends on the amount of available photosynthetic material in the early stages of growth or the capacity of the seeds to store the embryo. Therefore, every effect and reduction in the weight of 1000 seeds also affects the yield. The transfer of photosynthetic material from the source (leaf) to the sink (seed) can be a reason to increase the weight of 1000 seeds. In the investigation of Sadeghi and Kazemeini (2011), increasing the amount of nitrogen application increased the weight of 1000-seed in barley varieties. Since nitrogen fertilizer increases dry matter production and leaf area, barley grain also became heavier with increasing nitrogen application. The weight of 1000 seeds has a significant effect on germination, seedling, seedling establishment and crop production (Mohsen Nasab et al., 2010). The reduction in the weight of 1000 seeds in high densities may result from the superiority of vegetative organs in competing with reproductive organs (Gardner, 2007).

\section{Seed yield}

Based on the results of the analysis of variance, the effects of year, nitrogen and deterioration were significant on seed yield (Table 3). The comparison of means showed that the highest seed yield was obtained at all nitrogen levels in the second year and the lowest seed yield in the application was $15 \%$ higher than the recommended rate in the first year $(2971.3 \mathrm{~kg} / \mathrm{ha}$ ) (Table 4). In the second year, there was no significant statistical difference in seed yield, and the application of $30 \%$ more than the recommended nitrogen fertilizer had the highest mean $(4166.3 \mathrm{~kg} / \mathrm{ha})$. Among the levels of deterioration, the highest seed yield was achieved in the non-deteriorating at the second year $(4492.5 \mathrm{~kg} / \mathrm{ha})$ and the lowest average in 45 hours of deterioration level was found in the first year $(277.5 \mathrm{~kg} / \mathrm{ha})$ (Table 6). Among nutrients, nitrogen has the greatest effect on photosynthesis, therefore, increasing seed yield increased with increasing nitrogen applications. This could be due to the direct effect of nitrogen on the increase in seed yield due to increased vegetative growth because of the increased nitrogen levels resulting in higher seed yield. The seed yield also increased due to the higher number of seeds per spike and the weight of 1000 seeds. Reducing the number of seeds per spike will lead to reduced seed yield. Seed yield increases significantly with increasing nitrogen fertilizer. Nitrogen increases the amount of biomass and increases the possibility of retransmission of photosynthetic materials, producing more seed per spike and better seed filling after flowering, which will increase seed yield (Shanggan et al., 2000).

The seed deterioration treatments delayed the planting time and emergence and endangered the seeds viability and living conditions at the critical stage of seedling establishment, also reducing the uniformity of germination, which leads to a un-uniform establishment and reduced yield (Basra 
et al., 2003). With the increase in seed deterioration and reduction of seed vigor, germination percentage and speed of seed emergence in the field decrease, resulting in reduced plant density, reduced vegetative competition between plants, resulting in reduced processing time and ultimately reduced yield (Gharineh, 2004). The results of this experiment with the results of Rama (1999) reported that healthy wheat seeds had higher germination rates, therefore, increased seedling emergence, and resulted in higher seed yield. Deterioration of wheat seeds reduced the seed yield $40 \%-30 \%$ compared to the healthy wheat seeds (Dustenson, 1973).

In general, in order to obtain a desirable yield, it is necessary to have a strong and desirable vigor. Seed quality, directly and indirectly, affects plant yield. In addition, the high growth rate in strong seedlings can increase final yield (Kheshtzar and Siadat, 2015). With increasing deterioration, the strength and viability of the seeds decreases, and planting in the field reduces the percentage of emergence, produces poor seedlings, and ultimately decreases seed yield. The results of the experiment reported by Hampton (2003) that showed a reduction in seed yield of barley due to the deteriorating of the seeds are in agreement with the results of the present study.

\section{Straw yield}

Analysis of variance showed that the effects of year, density, deterioration, and interaction of nitrogen and density were significant on straw yield (Table 3). The straw yield in all three nitrogen levels in the second year was higher than in the first year (Table 4). Comparing the means of plant density showed that the second year was highest in both densities and the first year in both densities had the lowest mean of this trait (Table 5). Among the deterioration levels, the highest mean of this trait was in the second year and zero hours of the deteriorating level $(4439.2 \mathrm{~kg} / \mathrm{ha})$ and the lowest mean of this trait was obtained in 45 hours of deteriorating in the first year (1956.2 kg/ha) (Table 6).

\section{Biological yield}

Based on the results of the analysis of variance, the effects of year, density and deterioration were significant on biological yield (Table 3). The highest biological yield was obtained in the second year and at all three levels of nitrogen fertilizer, and the lowest mean of this trait was obtained in the first year at the three levels of nitrogen (Table 4). Among the plant densities, the highest biological yield was obtained in 420 plants $/ \mathrm{m}^{2}$ in the second year $(8352.1 \mathrm{~kg} / \mathrm{ha})$ and the lowest mean density was obtained in 350 plants $/ \mathrm{m}^{2}$ in the first year $(5559 \mathrm{~kg} / \mathrm{ha}$ ) (Table 5). Among the deterioration levels, the highest biological yield was observed in the second year $(8931.7 \mathrm{~kg} / \mathrm{ha})$ and the lowest average in the first year was $4531.4 \mathrm{~kg} / \mathrm{ha}$ and in the second year, the lowest average was $4931.4 \mathrm{~kg} / \mathrm{ha}$ (Table 6).

The effects of the application of the nitrogen fertilizer on biological yield were increased plant height; seed yield, leaf and stem dry weight, and tiller number, which led to an increase in biological yield. There are similar results reported by other investigators that show an increase in the biological yield due to increased nitrogen application (Ghobadi et al., 2010). McDonald (2002) also reported on wheat yield at different levels of nitrogen, which significantly increased dry matter during pollination with increased nitrogen application. Increase in the biological yield and straw yield has also been reported by other researchers with increased nitrogen fertilizer application (Bulman and Smith, 1993; Camberato and Bock, 2001). Increased seed yield due to nitrogen fertilization directly correlates with increase in the biological yield and the results of our experiment are in agreement with this fact. The high biological yield indicates the ability of the plant canopy to use environmental factors such as light and food to produce more dry matter. Therefore, it seems that increasing nitrogen application can increase the biological yield (Latiri-Souki et al., 1998).

Plant growth seems to be affected by the negative effects of seed deteriorating and has led to a decrease in its biological yield. The seed deteriorations with its effect on seed quality caused a decrease in emergence, seedling growth, biomass, and ultimately reduced biological yield, and reduced biological yield caused reduced seed yield. Increasing biological yield in higher densities seems to be related to more fertile crop per unit area. With density increases, the biological yield linearly increased (Ahern et al., 1995).

\section{Harvest index}

Effects of the year and deterioration were significant on harvest index (Table 3). Among the levels of seed deterioration, the highest harvest index was at the zero hour of deterioration in the second year $(50.83 \%)$ and the lowest was at the highest level of deteriorating (45 hours) with a mean of $38.77 \%$ (Table 6). Harvest index reflects the distribution of photosynthetic materials between the economic sink and other sinks in the plant. By increasing the nitrogen utilization due to the increase in foliage, a smaller portion of the photosynthetic materials is associated with the seeds, and hence the harvest index decreases. Increasing the harvest index indicates that the plant is more able to transfer and allocate more material to the aerial parts, and is one of the indicators used to evaluate the efficiency of the distribution of the dry matter of the agricultural crops. The ratio of seed dry matter to total plant dry matter is closely related to the number and 
activity of the production destinations, and since these breeding destinations are directly related to the growth rate of the plant. Therefore, under nitrogen deficiency condition, the growth rate of the plant is affected. Breeding reduces the ratio of seed dry matter to the total plant dry matter (Uhart and Andrade, 1995). There is a positive relationship between harvest index and seed yield (Fischer, 1999). Therefore, harvest index is also an important factor in increasing yield (Reynold and Rajarm, 1999). In grains, the increase in biomass has reached its final limit, hence the increase in seed yield through the allocation of more photosynthetic materials to the sink (seeds) is possible, in which case the harvest index will significantly increase (Krishnan et al., 2003).

\section{Protein content}

Effects of year, nitrogen, plant density, and seed quality were significant on protein content (Table 7). The highest protein content was achieved at the $30 \%$ nitrogen higher than the recommended rate level in the second year $(36.10 \%)$, which increased by about $8 \%$ of the total average. The lowest mean of this trait was observed at the recommended nitrogen rate level in the first year $(8.66 \%)$ (Table 8). Among the plant densities, the highest average protein percentage was obtained at 420 plants $/ \mathrm{m}^{2}$ in the first year $(11.30 \%)$, which increased by about $14 \%$ compared to the overall average. The lowest average was in the density of 350 plants $/ \mathrm{m}^{2}$ in the first year $(8.42 \%)$ (Table 9). Increasing nitrogen application rate caused a significant increase in seed protein content so that the highest protein percentage was in 45 hours of seed deterioration in the second year $(12.46 \%)$, which was about $25 \%$ higher than the overall average. The lowest mean of this trait was obtained in the non-deterioration treatment in the first year $(7.27 \%$ ) (Table 10). It has been reported that increased nitrogen application is effective in increasing protein content because nitrogen is one of the main structures of the steroidal amino acid, which further increases the protein content of the plant (Budakli et al., 2010). In a study, it was reported that with increasing seed deterioration the protein content of the seeds increased by $2 \%$ (Kheshtzar and Siadat, 2015).

\section{Protein yield}

Effects of year, nitrogen, plant density and seed quality were significant on protein yield (Table 7). The highest protein yield was found in the application of $30 \%$ nitrogen higher than the recommended rate treatment in the second year $(623.6 \mathrm{~kg} / \mathrm{ha})$, which increased by about $23 \%$ compared to the overall average. The lowest mean of this trait was achieved in the application of the recommended rate of nitrogen treatment in the first year (279.53 kg/ha) (Table 8). Among plant densities, the highest protein yield was found in the 420 plants $/ \mathrm{m}^{2}$ in the second year $(456.67 \mathrm{~kg} / \mathrm{ha})$, which increased by $28 \%$ compared to the overall average. The lowest mean of this trait was obtained in the density of 350 plants $/ \mathrm{m}^{2}$ in the first year $(258.24 \mathrm{~kg} / \mathrm{ha}$ ) (Table 9$)$. Protein yield increased significantly with increasing seed deterioration, so that in the 45 hours of seed deterioration treatment in the first year, the highest protein yield $(457.96 \mathrm{~kg} / \mathrm{ha}$ ) was obtained which increased by $26 \%$ compared to the overall average (Table 10). Application of nitrogen fertilizer affects protein accumulation and biomass production in wheat (Zorb et al., 2010). Wheat protein content is affected by agronomic management such as time and how nitrogen is applied,

Table 7: Combination ANOVA of some qualitative traits of wheat in two years (2015-2016)

\begin{tabular}{|c|c|c|c|c|c|c|}
\hline \multirow[t]{2}{*}{ Source of variation } & \multirow[t]{2}{*}{ df } & \multicolumn{5}{|c|}{ Mean square (MS) } \\
\hline & & Protein content & Protein yield & Nitrogen & Starch content & Starch yield \\
\hline Year (y) & 1 & $222.5^{\star \star}$ & $35979242938^{* *}$ & $5.69^{\star *}$ & $1943.6^{* *}$ & $1635230000^{* *}$ \\
\hline$r(y)$ & 6 & $6.38^{\star *}$ & $89139055^{\star \star}$ & $0.16^{\star \star}$ & $36.18^{\star \star}$ & $2317388841^{* *}$ \\
\hline Nitrogen $(\mathrm{N})$ & 2 & $14.82^{\star *}$ & $131197591^{\star *}$ & $0.37^{\star \star}$ & $122.54^{\star *}$ & $2651699808^{* *}$ \\
\hline Plant density (D) & 1 & $25.75^{\star *}$ & $195912107^{\star *}$ & $0.65^{\star *}$ & $0.07 \mathrm{~ns}$ & $1133018378^{* *}$ \\
\hline$N \times D$ & 2 & $2.33^{\star \star}$ & $19536148^{*}$ & $0.05^{\star *}$ & $13.36^{\star *}$ & $809598713^{*}$ \\
\hline$y \times N$ & 2 & $0.34 \mathrm{~ns}$ & $126447726^{\star *}$ & $0.008 \mathrm{~ns}$ & $0.14 \mathrm{~ns}$ & $2581027514^{* *}$ \\
\hline$y \times D$ & 1 & $0.19 \mathrm{~ns}$ & $187683873^{\star *}$ & $0.005 \mathrm{~ns}$ & $0.08 \mathrm{~ns}$ & $1087986872^{*}$ \\
\hline$y \times N \times D$ & 2 & $0.55^{\star}$ & $20252046^{\star}$ & $0.01^{*}$ & $0.27 \mathrm{~ns}$ & $834496386^{*}$ \\
\hline Error & 12 & 0.19 & 20069000 & 0.004 & 0.18 & 953172034 \\
\hline Seed quality $(\mathrm{Q})$ & 3 & $85.15^{\star *}$ & $14618306 \mathrm{~ns}$ & $2.17^{\star \star}$ & $349.81^{* *}$ & $12501861^{* *}$ \\
\hline$N \times Q$ & 6 & $0.80^{\star \star}$ & $13421184 \mathrm{~ns}$ & $0.02^{* \star}$ & $4.11^{*}$ & 259385913 ns \\
\hline$D \times Q$ & 3 & $1.13^{* *}$ & 6843088 ns & $0.02^{* \star}$ & $5.24^{*}$ & $116390608 \mathrm{~ns}$ \\
\hline$N \times D \times Q$ & 6 & $0.30^{*}$ & 4620857 ns & $0.007^{\star}$ & $1.81 \mathrm{~ns}$ & $125580215 \mathrm{~ns}$ \\
\hline$y \times Q$ & 3 & $0.02 \mathrm{~ns}$ & 13239054 ns & $0.0006 \mathrm{~ns}$ & $0.16 \mathrm{~ns}$ & $12013969355^{\star \star}$ \\
\hline $\mathrm{y} \times \mathrm{N} \times \mathrm{D} \times \mathrm{Q}$ & 15 & $0.03 \mathrm{~ns}$ & 8402695 ns & $0.0008 \mathrm{~ns}$ & $0.21 \mathrm{~ns}$ & $175276328 \mathrm{~ns}$ \\
\hline Experimental Error & 126 & 0.13 & 6261169 & 0.003 & 1.74 & 224479215 \\
\hline CV (\%) & - & 6.65 & 17.70 & 3.65 & 5.14 & 15.78 \\
\hline
\end{tabular}

${ }^{*}$ and ${ }^{* *}$ : Significant at $5 \%$ and $1 \%$ probability levels, respectively. ns : nonsignificant 
Mosanaei, et al.: Effect of nitrogen and plant density on wheat

Table 8: Grouping the mean effect of nitrogen levels on some qualitative traits of wheat in two years (2015-2016)

\begin{tabular}{|c|c|c|c|c|c|c|c|c|c|c|}
\hline \multirow[t]{2}{*}{$\begin{array}{l}\text { Nitrogen fertilizer } \\
\text { levels }\end{array}$} & \multicolumn{2}{|c|}{$\begin{array}{c}\text { Protein content } \\
(\%)\end{array}$} & \multicolumn{2}{|c|}{$\begin{array}{l}\text { Protein yield } \\
\text { (Kg/ha) }\end{array}$} & \multicolumn{2}{|c|}{$\begin{array}{c}\text { Nitrogen content } \\
(\%)\end{array}$} & \multicolumn{2}{|c|}{$\begin{array}{c}\text { Starch content } \\
(\%)\end{array}$} & \multicolumn{2}{|c|}{$\begin{array}{l}\text { Starch yield } \\
\text { (Kg/ha) }\end{array}$} \\
\hline & $1^{\text {st }}$ year & $2^{\text {nd }}$ year & $1^{\text {st }}$ year & $2^{\text {nd }}$ year & $\begin{array}{c}1^{\text {st }} \\
\text { year }\end{array}$ & $2^{\text {nd }}$ year & $1^{\text {st }}$ year & $2^{\text {nd }}$ year & $1^{\text {st }}$ year & $2^{\text {nd }}$ year \\
\hline $\begin{array}{l}\text { Advised amount of } \\
\text { nitrogen }\end{array}$ & $8.66 \mathrm{~d}$ & $9.40 \mathrm{c}$ & $279.53 \mathrm{~d}$ & $381.81 \mathrm{~b}$ & $1.43 \mathrm{~d}$ & $1.50 \mathrm{c}$ & $61.46 \mathrm{~b}$ & $63.19 \mathrm{a}$ & $1983.86 \mathrm{c}$ & $2566.71 \mathrm{a}$ \\
\hline $\begin{array}{l}15 \text { percent higher } \\
\text { than advised amount } \\
\text { of nitrogen }\end{array}$ & $9.12 \mathrm{~cd}$ & $9.92 \mathrm{~b}$ & $270.98 d$ & $392.27 \mathrm{~b}$ & $1.54 \mathrm{bc}$ & $1.58 \mathrm{~b}$ & $58.94 \mathrm{bc}$ & $61.02 \mathrm{~b}$ & $1751.28 d$ & $2412.97 \mathrm{~b}$ \\
\hline $\begin{array}{l}30 \text { percent higher } \\
\text { than advised amount } \\
\text { of nitrogen }\end{array}$ & $9.99 \mathrm{~b}$ & $10.36 \mathrm{a}$ & $337.55 \mathrm{c}$ & $431.62 \mathrm{a}$ & $1.62 \mathrm{a}$ & $1.65 \mathrm{a}$ & $55.75 \mathrm{c}$ & $60.62 \mathrm{~b}$ & $1883.73 \mathrm{~cd}$ & $2525.61 \mathrm{a}$ \\
\hline Mean & \multicolumn{2}{|c|}{9.57} & \multicolumn{2}{|c|}{348.96} & \multicolumn{2}{|c|}{1.55} & \multicolumn{2}{|c|}{60.19} & \multicolumn{2}{|c|}{2187.36} \\
\hline
\end{tabular}

In each column, means with similar letters have no significant difference at the $5 \%$ probability level, based on the LSD test

Table 9: Grouping the mean effect of plant density on some qualitative traits of wheat in two years (2015-2016)

\begin{tabular}{|c|c|c|c|c|c|c|c|c|c|c|}
\hline \multirow[t]{2}{*}{ Plant density } & \multicolumn{2}{|c|}{ Protein content (\%) } & \multicolumn{2}{|c|}{ Protein yield (Kg/ha) } & \multicolumn{2}{|c|}{ Nitrogen content (\%) } & \multicolumn{2}{|c|}{ Starch content (\%) } & \multicolumn{2}{|c|}{ Starch yield (Kg/ha) } \\
\hline & $1^{\text {st }}$ year & $2^{\text {nd }}$ year & $1^{\text {st }}$ year & $2^{\text {nd }}$ year & $1^{\text {st }}$ year & $2^{\text {nd }}$ year & $1^{\text {st }}$ year & $2^{\text {nd }}$ year & $1^{\text {st }}$ year & $2^{\text {nd }}$ year \\
\hline $\begin{array}{l}350 \text { plants } \\
\text { per } \mathrm{m}^{2}\end{array}$ & $8.42 \mathrm{~d}$ & $10.64 \mathrm{~b}$ & $258.24 d$ & $422.79 \mathrm{~b}$ & $1.34 \mathrm{~d}$ & $1.70 \mathrm{~b}$ & $58.39 \mathrm{a}$ & $64.79 \mathrm{a}$ & $1824.00 \mathrm{~b}$ & $2587.10 \mathrm{a}$ \\
\hline $\begin{array}{l}420 \text { plants } \\
\text { per } \mathrm{m}^{2}\end{array}$ & $9.22 \mathrm{c}$ & $11.30 \mathrm{a}$ & $298.21 \mathrm{c}$ & 465.67 a & $1.47 \mathrm{c}$ & $1.80 \mathrm{a}$ & $58.47 \mathrm{a}$ & $64.70 \mathrm{a}$ & $1920.19 b$ & $2684.62 \mathrm{a}$ \\
\hline Mean & \multicolumn{2}{|c|}{9.89} & \multicolumn{2}{|c|}{361.22} & \multicolumn{2}{|c|}{1.57} & \multicolumn{2}{|c|}{61.58} & \multicolumn{2}{|c|}{2253.97} \\
\hline
\end{tabular}

In each column, means with similar letters have no significant difference at the $5 \%$ probability level, based on the LSD test

Table 10: Grouping the mean effect of seed quality on some qualitative traits of wheat in two years (2015-2016)

\begin{tabular}{|c|c|c|c|c|c|c|c|c|c|c|}
\hline \multirow{2}{*}{$\begin{array}{l}\text { Decadence } \\
\text { levels (hour) }\end{array}$} & \multicolumn{2}{|c|}{ Protein content (\%) } & \multicolumn{2}{|c|}{ Protein yield (Kg/ha) } & \multicolumn{2}{|c|}{ Nitrogen content (\%) } & \multicolumn{2}{|c|}{ Starch content (\%) } & \multicolumn{2}{|c|}{ Starch yield $(\mathrm{Kg} / \mathrm{ha})$} \\
\hline & $1^{\text {st }}$ year & $2^{\text {nd }}$ year & $1^{\text {st }}$ year & $2^{\text {nd }}$ year & $1^{\text {st }}$ year & $2^{\text {nd }}$ year & $1^{\text {st }}$ year & $2^{\text {nd }}$ year & $1^{\text {st }}$ year & $2^{\text {nd }}$ year \\
\hline Control ( 0) & $7.27 f$ & $9.44 d$ & $271.63 d$ & $425.44 \mathrm{bc}$ & $1.16 \mathrm{f}$ & $1.51 \mathrm{~d}$ & $61.60 \mathrm{~d}$ & $68.13 \mathrm{a}$ & 2294.6 c & $3063.1 \mathrm{a}$ \\
\hline 15 & $8.24 \mathrm{e}$ & $10.44 \mathrm{c}$ & $266.57 \mathrm{~d}$ & $415.96 \mathrm{c}$ & $1.31 \mathrm{e}$ & $1.67 \mathrm{c}$ & $59.53 \mathrm{e}$ & $65.81 \mathrm{~b}$ & $1915.4 \mathrm{~d}$ & $2612.8 b$ \\
\hline 30 & $9.40 d$ & $11.54 \mathrm{~b}$ & $286.29 d$ & $477.57 \mathrm{a}$ & $1.50 \mathrm{~d}$ & $1.84 \mathrm{~b}$ & $56.94 \mathrm{f}$ & $63.22 \mathrm{c}$ & $1732.7 \mathrm{de}$ & $2600.7 b$ \\
\hline 45 & $10.36 \mathrm{c}$ & $12.46 \mathrm{a}$ & $288.40 \mathrm{~d}$ & $457.96 \mathrm{ab}$ & $1.65 \mathrm{c}$ & $1.99 \mathrm{a}$ & $55.63 \mathrm{~g}$ & $62.00 \mathrm{~d}$ & $1545.6 \mathrm{e}$ & $2266.8 \mathrm{c}$ \\
\hline Mean & \multicolumn{2}{|c|}{9.89} & \multicolumn{2}{|c|}{361.22} & \multicolumn{2}{|c|}{1.57} & \multicolumn{2}{|c|}{61.60} & \multicolumn{2}{|c|}{2253.96} \\
\hline
\end{tabular}

In each column, means with similar letters have no significant difference at the $5 \%$ probability level, based on the LSD test.

type of genotype, and the environmental conditions in the pre- and post-pollination stages as well as by the interaction between the environmental factors and type of genotype (Lemon, 2007). In most studies, increased nitrogen fertilization has increased the protein content of grain (Fowler, 2003). Since nitrogen remobilization from vegetative organs to seed plays a significant role in grain protein content, distribution of stored nitrogen in vegetative organs and transferring it to seeds under stress conditions is very important (Madhaj et al., 2009).

\section{Nitrogen content}

Effects of year, nitrogen, plant density and seed quality were significant on nitrogen content (Table 7). Increasing amount of nitrogen used showed a significant increase in seed nitrogen content. The highest mean of this trait was found in the $30 \%$ nitrogen more than the recommended rate treatment in the second and the first year $(1.65 \%$ and $1.62 \%$, respectively) and the lowest average was obtained in the application of the recommended rate of nitrogen in the first year $(1.43 \%$ ) (Table 8$)$. Among the plant densities, the density of 420 plants $/ \mathrm{m}^{2}$ in the second year was the highest $(1.80 \%)$ and the density of 350 plants $/ \mathrm{m}^{2}$ in the first year had the lowest average (34.1\%) (Table 9). The seed deteriorations caused increased nitrogen content of the seeds, the highest nitrogen percentage was in the 45 hours of deterioration in the second year $(1.99 \%)$ and the lowest mean was in the non-deterioration treatment in the first year $(1.16 \%)$ (Table 10). Increasing the amount of nitrogen available to the plant increases the vegetative growth rate in the plant, resulting in a higher percentage of nitrogen in the plant (Vos et al., 2005). The fact that nitrogen is one of the most important elements in increasing the nitrogen content of seed, it seems that increased application of nitrogen fertilizer caused increases in the accumulation of this element in grain. These results are similar to the results of other researchers who reported that nitrogen concentration in plants increased with increasing nitrogen fertilizer applications (Garrido- Lestache et al., 2005).

\section{Starch content}

The effect of year, nitrogen and seed deterioration were significant on the starch content (Table 7). The highest starch percentage was achieved in the nitrogen application 
of the recommended rate in the second year $(63.19 \%)$, which increased by $5 \%$ compared to the overall average. The lowest mean was obtained in the application of 30\% nitrogen more than the recommended rate in the first year $(55.75 \%)$ (Table 8$)$. No statistically significant difference was observed between the plant densities in terms of starch content. The seed deteriorations reduced the starch content the highest mean was observed in the non-deterioration treatment in the second year $(68.13 \%)$, which increased by $10 \%$ compared with the overall average. The lowest mean was recorded in the highest level of deterioration treatment (45 hours) in the first year (55.63\%) (Table 10). One of the possible causes of seed deterioration is the formation and activation of hydrolyzing enzymes. This results in the decomposition of plant carbohydrate reserves. The higher the degree of seed deterioration, the greater the decomposition of the stored carbohydrates such as starch, and the content of these reserves will decrease (Krishnan et al., 2003). This confirms the results of the present study.

\section{Starch yield}

The results of the analysis of variance showed that the effect of year, nitrogen, plant density, and seed quality were significant on the starch yield (Table 7). The highest starch yield was in the application of recommended nitrogen and $30 \%$ higher than the recommended rate in the second year (2566.71 and $2525.61 \mathrm{~kg} / \mathrm{ha}$, respectively), which increased 15 and $13 \%$, respectively, compared to the overall average. The lowest mean was obtained in the application of recommended nitrogen rate in the first year with a mean of $1983.86 \mathrm{~kg} / \mathrm{ha}$ (Table 8). Among the plant densities, both densities were the highest in the second year and in the first year the lowest average starch yield was observed (Table 9). Among the levels of seed deterioration, the highest starch yield was achieved in the non-deterioration of seed for the second year with an average of $3063.1 \mathrm{~kg} / \mathrm{ha}$, which was $36 \%$ higher than the overall average (Table 10). Starch is part of the insoluble carbohydrates in the seeds, it is broken down due to the deterioration of the seed and increased activity of the hydrolyzing and degrading enzymes of the starch and it is converted to glucose. On the other hand, the produced glucose due to decreased activity of the enzymes involved in the decomposition of the seed storage substances or enzymes involved in the production of new tissues cannot be present in growing plants, therefore, the amount of starch decreases (Lehner et al., 2008; Krishnan et al., 2003).

\section{CONCLUSIONS}

Considering the importance of seed health, it is necessary to study the effects of deterioration on seed germination and plant establishment and yield. Nitrogen is one of the most important limiting factors in plant growth. Nitrogen application in a recommended amount based on soil test resulted in an increase of quantitative and qualitative yields. Considering the higher rainfall and less variation in the climate in the second year of the experiment, all traits measured in the second year were better than the first year and the mean of traits measured in all traits was higher. Deterioration of seeds is a plant stress and reduces the plant's storage capacity (such as starch). In order to cope with this stress, the amount of protein and various enzymes increase and thus cause loss of yield and yield components. However, the results showed that the application of nitrogen fertilizer higher than the recommended rate at a higher density ( 420 plants $/ \mathrm{m}^{2}$ ) improved yield and yield components under these conditions and prevented a decrease in the average of the traits. According to the results of this study, it is recommended that before planting, quality assurance tests on the seeds should be carried out, because the heat and moisture content of the storage can reduce the seed vigor and viability (reduce germination, reduce normal seedlings, etc.) even in the most resistant cultivars, and finally the reduction of yield components, especially the number of spikes per $\mathrm{m}^{2}$, the number of seeds per spike, and the weight of 1000-seed, consequently, caused a decrease in the grain yield and the harvest index. According to the results, it can be said that the use of high-quality seeds with strong vigor, in addition to the superiority of the plant during the growth stages, can increase the seed yield. The present research is one of the leading researches on the effect of seed bulkiness and density on wheat yield, which provides the basis for further research.

\section{Authors contributions}

Hedieh Mosanaei conducted the experiment, analyzed and discussed the results, and drafted the manuscript. Hossein Ajamnorozi supervised and designed the research. Mohammad Reza Dadashi and Abolfazleh Faraji served as the committee members of the senior author and reviewed the first draft of the manuscript. Mohammad Pessarakli consulted in preparation and writing the manuscript and improved the English version of it.

\section{REFERENCES}

Ahern, F. O., M. Bever, A. Campbell and M. Therrien. 1995. Production and Feeding of Hull-Less Barley. Agricultural and AgriculturalFood, Canada Publication, Canada, p. 21.

Brown, B., M. Westcott, N. Christensen, B. Pan and J. Stark. 2005. Nitrogen Management for Hard Wheat Protein Enhancement, Pacific Northwest Extension Publication, PNW 578.

Budakli, C. E., N. Celik and G. Bayram. 2010. Yield and quality of forage maize as influenced by plant density and nitrogen rate. Turk. J. Field. Crops. 15(2): 128-132.

Bulman, P. and D. L. Smith. 1993. Yield and yield and components response of spring barley to fertilizer nitrogen. Agron. J. 85: 226-231. 
Camberato, J. and J. B. R. Bock. 2001. Spring wheat response to enhanced a minimum supply. Agron. J. 82: 467-473.

Dianne, C. F., W. Randy, H. Ronnie, M. S. Paul and G.W. Seffery. 2006. Minimizing protein variability in soft red winter wheat: Impact of nitrogen application timing and rate. Agron. J. 98: 1137-1145.

Donald, C. M. 1986. The breeding of crop ideotypes. Euphytica. 17: 385-403.

Dustenson, M. 1973. Analysis of interrelationships among seedling vigor fields emergence and yield in wheat. Agron. J. 64: 417-22.

Ercoli, L., L. Lulli, M. Mariotti, A. Masoni and I. Arduini. 2008. Postanthesis dry matter and nitrogen dynamics in durum wheat as affected by nitrogen supply and soil water availability. Eur. J. Agron. 28: 138-147.

Fischer, R. A. 1999. Irrigated spring wheat and timing and the amount of nitrogen fertilizer. Field Crops Res. 33: 57-80.

Fowler, B. D and J. Brydon. 2001. No-till winter wheat production on the Canadian prairies. Agron. J. 81: 817-825.

Fowler, D. B. 2003. Crop nitrogen demand and grain protein concentration of spring and winter wheat. Agron. J. 95: 260-265.

Garcia del Moral, L. F., M. Belen, J. L. Garcia del Moral, A. MolinaCanoe and A.G. Slafer. 2003. Yield stability and development in two and six rowed winter barleys under mediterranean conditions. Field Crops Res. 81: 109-119.

Gardner, F. 2007. Crops Physiology. Jahad Daneshgahi Press of Mashhad, Mashhad, p. 300.

Garrido-Lestache, E., R. J. Lopez-Bellido and L. Lopez-Bellido. 2005. Durum wheat quality under mediterranean conditions as affected by $\mathrm{N}$ rate, timing and splitting, $\mathrm{N}$ form and $\mathrm{S}$ fertilization. Eur. J. Agron. 23: 265-278.

Gharineh, M. H., A. M. Bakhshandeh and K. Ghassemi-Golezani. 2004. Effects of viability and vigor of seed on establishment and grain yield of wheat cultivars in field conditions. Seed Plant Prod. 20(3): 383-400.

Ghobadi, M., M. E. Ghobadi and S. S. Sayah. 2010. Nitrogen application management in triticale under post-anthesis drought stress. Word Acad. Sci. Eng. Technol. 70: 252-254.

Hampton, J. G. 2003. Methods of viability and vigor testing: A critical and appraisal. In: Basra, A. S. (Ed.), Seed Quality, Basic Mechanisms, and Agricultural Implications. CBS Publishers and Distributes, New Delhi, India, pp. 81-118.

Hastrop, P. I., P. E. Jourgenson and I. Ploulsen. 1993. Effect of seed vigor and dormancy of field emergence development and grain yield of winter bit and winter barley. Seed Sci. Technol. 21: 159-178.

Hellubust, J. A and J. S. Caraigie. 1978. Handbook of Physiological Methods: Physiological and Biochemical Methods. Cambridge University Press, London.

Hiltbrunner, J., B. Streit and M. Lidgens. 2007. Are seeding densities an opportunity to increase grain yield of winter wheat in a living mulch of white clover? Field Crops Res. 102: 163-171.

Kheshtzar, M. and S. A. Siadat. 2015. Study of effect seed deterioration and plant density on yield and yield components of hull-less barley. Agric. Crop Manage. 16(4): 829-838.

Krishnan, P., S. Nagarajan, M. Dadlani and A. V. Moharir. 2003. Characterization of wheat (Triticum aestivum L.) and soybean (Glycine max L.) seeds under accelerated aging conditions by proton nuclear magnetic spectroscopy. Seed Sci. Technol. 31: 541-550.

Latiri-Souki, K., S. Nortcliff and D. W. Lawlor. 1998. N fertilizer can increase dry matter production, grain yield and radiation and water use efficiencies of wheat under semi-arid conditions. Eur. J. Agron. 9: 34-21.

Lehner, A., N. Mamadou, P. Poels, D. Come, C. Baily and F. Corbineau. 2008. Changes in soluble carbohydrates, lipid peroxidation and antioxidant enzyme activities in the embryo during aging in wheat grains. J. Cereal Sci. 47: 555-565.

Lemon, J. 2007. Nitrogen management for wheat protein and yield in the esperance port zone. Department of Agriculture and Food Publisher, Western Australia, p. 25.

Lv, Y., S. Zhang, J. Hu and Y. Wang. 2016. Quantitative proteomic analysis of wheat seeds during artificial aging and priming using the isobaric tandem mass tag labeling. PLoS One. 11(9): e0162851.

Madhaj, A., A. Naderi, Y. Emam, A. Ayneband and G. Normohammadi. 2009. Effect of different nitrogen levels on grain yield, grain protein content and agronomic nitrogen use efficiency in wheat genotypes under optimum and post-anthesis heat stress conditions. Seed Plant Prod. 25(4): 353-371.

McDonald, G. K. 2002. Effects of nitrogen fertilizer on the growth grain yield and grain protein concentration of wheat. Aust. J. Agric. Res. 43: 949-967.

McDonald, C. M., C. D. Floyd and R. D. Waniska. 2004. Effect of accelerated aging on maize, sorghum, and sorghum. J. Cereal Sci. 39: 351-301.

Melero, S., R. J. Lopez-Bellido, L. Lopez-Bellido, V. N. MunozRomero, F. Moreno, M. Murillo and A. J. Franzluebbers. 2012. Stratification ratios in a rainfed mediterranean vertisol in wheat under different tillage, rotation, and $\mathrm{N}$ fertilization rates. Soil Tillage Res. 119: 7-12.

Modarresi, R., M. Rucker and D. M. Tekrony. 2002. Accelerating aging test for comparing wheat seed vigor. Seed Sci. Technol. 30: 683-687.

Moghaddam, M., B. Ehdaie and E. Waines. 1997. Genetic variation and inter relationships of agronomic characters in landraces of bread wheat from South-Eastern Iran. Euphytica. 95: 361-369.

Mohsen, N. F., M. Sharifizadeh and A. S. Sayyidat. 2010. Effect of seed deteriorates on seedling establishment, yield and yield components of wheat cultivars under khuzestan climate. J. Sci. Plant Growth. 2(6): 13-29.

Nourmohammadi, G.H., A. Siadat and A. Kashani. 2010. Cereal Crops, Ninth Printing. Chamran University Press, Ahvaz, Iran, p. 48.

Parvane, V. 2005. Food Qualitative Control and Chemical Experiments. Tehran University Press, Tehran, p. 332.

Peng, B. 2011. Effect of controlled overexpression of glucokinase by different promoters on xylose metabolism in Saccharomyces cerevisiae. Wei Sheng Wu Xue Bao. 51(7): 914-922.

Powell, A. A. 1998. Seed vigor and field establishment. Univ. UK. Dept. Agric. 11: 29-80.

Qi, J. C., G. P. Zhang and M. X. Zhon. 2006. Protein and hordein content in barley seeds as affected by nitrogen level and their relationship to beta-amylase activity. J. Cereal Sci. 43: 102-107.

Rama, C., P. Kumari, O. Singh and R. K. Sadana. 1999. The relationship between seed vigor tests and field emergence in chickpea. Seed Sci. Technol. 17: 169-173.

Reynold, M. P. and S. Rajarm. 1999. Physiological and genetic changes of irrigated wheat in the post green revolution period and approaches for meeting projected global demand. Crop Sci. 39: 1611-1621.

Royo, C., D. Villegas, Y. Rharrabti, R. Blanco, V. Martos and L. F. G. Delmoral. 2006. Grain growth and yield formation of durum wheat grown at contrasting latitudes and water regimes in 
a mediterranean environment. Cereal Res. Commun. 34: 1021-1028.

Sabbr, Z., H. A. Peirdashti, M. A. Esmaili and A. Abassian. 2011. Evaluation of growth promoting bacteria, nitrogen, and phosphorus on fertilizer efficiency and yield of wheat. Agroecology. 5(1): 39-49.

Sadeghi, H. and A. R. Kazemeini. 2011. Effect of crop residue management and nitrogen fertilizer on grain yield and yield components of two barley cultivars under dry land conditions. Iran. J. Crop Sci. 13(3): 436-451.

Shanggan, Z. P., A. Shao and J. Dychmans. 2000. Nitrogen nutrition and water stress effects on leaf photosynthetic gas exchange and water use efficiency in winter wheat. Environ. Exp. Bot. 44: 141-149.

Sieling, K., C. Stahl, C. Winkelmann and O. Christen. 2005. Growth and yield of winter wheat in the first 3 years of a monoculture under varying $\mathrm{N}$ fertilization in NW Germany. Eur. J. Agron. 22: 71-84.

Soltani, E., S. Galeshi, B. Kamkar and F. Akramghaderi. 2009. The effect of seed aging on the seedling growth as affected by environmental factors in wheat. Res. J. Environ. Sci. 3: 184-192.

Šramková, Z., E. Gregová and E. Šturdík. 2009. Chemical composition and nutritional quality of wheat grain. Acta Chim. Slov. 2: 115-138.

Srivastava, R. D. L and O. N. Mehrotra. 1981. Physiological studies on nutrition of dwarf wheat. IV. Effect of rate and method of nitrogen application on yield and yield components of wheat.
Indian J. Agric. Chem. 14(1-2): 139-147.

Tekrony, D. M and D. B. Egli. 1991. Relation ship of seed vigor to crop yield: A review. Crop Sci. 31(3): 816-822.

Uhart, S. A. and F. H. Andrade. 1995. Nitrogen deficiency in maize: I. Effects on crop growth, development dry matter partitioning and kernel set. Crop Sci. 35: 1376-1383.

Victim, M., A. Soltani and Q. Amiri. 2005. Effect of salinity and seed size on germination and seedling growth of wheat. J. Agric. Sci. Nat. Res. 14(6): 60-56 .

Vos, J., P. E. L. Putten and C. J. Birch. 2005. Effect of nitrogen supply on leaf appearance, leaf nitrogen economy and photosynthetic maize (Zea mays L.). Field Crop Res. 93: 64-73.

Warraich, E. A., S. M. A. Basra, N. Ahmad and R. M. A. Aftab. 2002. Effect of nitrogen on grain quality and vigor in Wheat (Triticum aestivum L.). Inter. J. Agric. Biol. 4: 517-520.

Wysocki, D. J., M. Corp, D. A. Horneck and L. K. Lutcher. 2007. Nutrient Management Guide: Irrigated and Dryland Canola. Oregon State University EM-8943-E. Available from: http://www. extension.oregonstate.edu/catalog/pdf/em/em8943-e.pdf .

Xi-Haun, L., C. Wen-Suo, C. Cai-Ying, L. Bao and M. Zhi-Ying. 2008. Relations between sowing date, seeding density and grain yield of two introduced malting barley varieties. J. Agric. Univ. Hebei. 31: 6-11.

Zorb, C., C. Grover, D. Steinfurth and K. H. Muhling. 2010. Quantitative proteome analysis of wheat gluten as influenced by $\mathrm{N}$ and $\mathrm{S}$ nutrition. Plant Soil. 327(1-2): 225-234. 